\title{
IDŐJÁRÁS
}

Quarterly Journal of the Hungarian Meteorological Service

Vol. 124, No. 2, April-June, 2020, pp. 209-225

\section{Estimation of agro-ecosystem services using biogeochemical models}

\author{
Klára Pokovai ${ }^{1, *}$, Roland Hollós ${ }^{2,3}$, Emese Bottyán ${ }^{2,3}$, Anna Kis ${ }^{2,3}$, \\ Tibor Marton ${ }^{6}$, Rita Pongrácz ${ }^{2,3}$, László Pásztor ${ }^{5}$, Dóra Hidy ${ }^{2,3}$, \\ Zoltán Barcza ${ }^{2,3,4}$, and Nándor Fodor ${ }^{6}$
}

\author{
${ }^{1}$ Department of Soil Physics and Water Management \\ Institute for Soil Sciences and Agricultural Chemistry \\ Centre for Agricultural Research, Hungarian Academy of Sciences, \\ H-1022 Budapest, Herman Ottó út 15, Hungary \\ ${ }^{2}$ Department of Meteorology, Eötvös Loránd University, \\ H-1117 Budapest, Pázmány P. sétány 1/A, Hungary \\ ${ }^{3}$ Excellence Center, Faculty of Science, Eötvös Loránd University, \\ H-2462 Martonvásár, Brunszvik u. 2, Hungary \\ ${ }^{4}$ Faculty of Forestry and Wood Sciences \\ Czech University of Life Sciences \\ Prague, 16521 Prague 6, Kamýcká 129, Czech Republic \\ ${ }^{5}$ Department of Soil Mapping and Environmental Informatics \\ Institute for Soil Sciences and Agricultural Chemistry \\ Centre for Agricultural Research, Hungarian Academy of Sciences, \\ H-1022 Budapest, Herman Ottó út 15, Hungary \\ ${ }^{6}$ Crop Production Department, Agricultural Institute \\ Centre for Agricultural Research, Hungarian Academy of Sciences, \\ H-2462 Martonvásár, Brunszvik u. 2, Hungary \\ *Corresponding author E-mail: pokovai.klara@agrar.mta.hu
}

(Manuscript received in final form July 5, 2019) 


\begin{abstract}
Agro-ecosystem services are the various benefits (e.g., crop yield) that people freely obtain from the properly functioning agricultural lands. The estimated changes in climatic conditions including increasing temperature, with particular attention to the summer means, together with the expected changes in the temporal precipitation distribution pose enormous challenge to the agriculture. Currently, dynamic system models are most frequently used tools that are capable of estimating the prospective effects of climate change on agro-ecosystems. A deterministic biogeochemical model is presented that is developed by Hungarian scientists within the framework of the AgroMo project. The main goal of the AgroMo project is to develop climate-smart strategies in order to mitigate the effect of potential future hazards in the context of climate change by 1) creating a complex, state-of-the-art experimental platform; 2) producing ten new, $0.1^{\circ}$ spatial resolution climate scenarios based on the RCP (Representative Concentration Pathway) 4.5 and RCP8.5 scenarios; 3) developing an integrated assessment and modeling framework that is capable of simulating every major land use types; 4) analyzing/simulating a great number of adaptation strategies that can be used to support decision makers. Based on the preliminary simulation results, climate change will most likely expose significant negative impact on the spring sown crops in Hungary. Although, the yield losses could be avoided with irrigation or could be mitigated with earlier sowing, the role of winter crops is likely to become more significant in Hungary in the future.
\end{abstract}

Key-words: model, simulation, climate change, crop yield, nitrate leaching, decision support

\title{
1. Introduction
}

Ecosystem services are the various benefits that people freely obtain from the properly functioning natural environment. Agricultural ecosystems cover nearly $40 \%$ of the terrestrial ecosystems $(F A O, 2017)$. Their role is essential in human wellbeing, while food, forage, natural fibre, timber and biomass fuels, pharmaceuticals, and other biochemicals and products from floriculture are essential agro-ecosystem services as well as such non-marketed services like regulation of soil and water quality, carbon sequestration, support of biodiversity and cultural services (Power, 2010), pest and disease regulation as well as climate regulation (Jarvis et al., 2011). Malfunctioning agro-ecosystems also can be a source of disservices, like loss of wildlife habitat, nutrient runoff, sedimentation of waterways, greenhouse gas emissions, pesticide poisoning of humans and nontargeted species (Power, 2010). Global food security is a major area of interest of all these agro-ecosystem services and disservices. According to relevant statistics, at present over 800 million people remain food insecure $(F A O, 2017)$. Scientists repeatedly call attention on climate change that could potentially interrupt progress toward a world without hunger. Studies support the need for considerable investment in adaptation and mitigation actions toward a "climate-smart food system" that is more resilient to climate change influences on food security (Wheeler and von Braun, 2013). 
Recent global climate change is thought to be caused by increasing atmospheric greenhouse gas concentration, which is in large part the consequence of human activity, mainly fossil fuel combusting, cement production, and land use change (Stocker et al., 2013). The global mean surface temperature has increased since the late 19th century, and each of the past three decades has been warmer than all the previous ones (Stocker et al., 2013). In Hungary, the first decade of the 21st century (2001-2010) was the warmest period since 1901. The average temperature was $0.7^{\circ} \mathrm{C}$ warmer than the 30-year (1970-2000) average (Lakatos and Bihari, 2011). Precipitation measurements suggest that the overall intensity and frequency of extreme precipitation events - related to both the excess and lack of precipitation - increased in the 1901-2009 period and, at the same time, the total precipitation slightly decreased (Bartholy and Pongrácz, 2005; Lakatos et al., 2011).

In order to quantitatively evaluate the future climate change, global climate models (GCMs) were applied in the framework of climate model intercomparison projects (e.g., CMIP3, CMIP5; (Knutti and Sedláček, 2012; Meehl et al., 2007; Taylor et al., 2011). Continuous warming is projected for Europe according to climate model simulations with an annual mean temperature of $1-5.5^{\circ} \mathrm{C}$ higher in 2071-2100 than in 1971-2000. A continental warming of $1-4.5^{\circ} \mathrm{C}$ and $2.5-$ $5.5^{\circ} \mathrm{C}$ is projected by the new ensemble of regional climate model (RCM) simulations from the EURO-CORDEX program for RCP4.5 and RCP8.5, respectively (Jacob et al., 2014).

Pieczka et al. (2018) has provided downscaled temperature time fields for the Carpathian Basin with $10 \mathrm{~km}$ horizontal resolution using the RCP4.5 and RCP8.5 scenarios. Simulations for the whole 21 st century using either scenario show a clear warming trend with the largest estimated changes in summer, and the smallest changes in spring. Spatial average temperature changes are $2.4{ }^{\circ} \mathrm{C}$ and $5.1^{\circ} \mathrm{C}$ in the last 20 years of the 21 st century compared to the $1981-2000$ reference period, with $3.6^{\circ} \mathrm{C}$ and $6.9^{\circ} \mathrm{C}$ projected warming in the summer months. In case of temperature related extreme events, e.g., hot days (when daily $\operatorname{Tmax}>30^{\circ} \mathrm{C}$ ) and tropical nights (when daily $\operatorname{Tmin}>20^{\circ} \mathrm{C}$ ), significant increase is projected for the 21 st century. Precipitation projections for the Carpathian Basin indicate that substantially drier climatic conditions are likely for summer (Kis et al., 2017) on the basis of the results of 11 RCM simulations. In addition, the length of summer dry periods and the total number of dry days are projected to increase. The temporal precipitation distribution seems to be restructured by the end of the 21 st century, namely the currently wettest season (summer) can become the driest and the currently driest season (winter) will become the wettest if greenhouse gas concentration continue to increase throughout the century (Pongrácz et al., 2014).

As the Carpathian Basin is located in a transitional zone between a warmer Mediterranean (where a general drying is expected) and a colder continental climate (where overall wetter conditions are projected), the uncertainty of GCM projections are quite high (Stocker et al., 2013). It means that further 
investigations on finer spatial resolution are needed to get more precise information on the future climatic conditions (Kis et al., 2017).

The estimated changes in climatic conditions including increasing annual mean temperature, with particular attention to the summer means, together with the expected changes in the temporal precipitation distribution pose enormous challenge to the agriculture. Currently, dynamic system models (crop models) are the most frequently used tools that are capable of estimating the prospective effects of climate change on agro-ecosystems (Fodor et al., 2017). Coupling of crop models with climate change scenarios, this crop-climate modeling is essential to the development of future agricultural outlooks that can inform policy processes and/or field-level decisions (Porter et al., 2014). It can be suitable for (i) deriving stakeholder-driven portfolios of options for farmers, communities, and countries; (ii) ensuring that adaptation actions are relevant to those most vulnerable to climate change; and (iii) combining adaptation and mitigation (Campbell et al., 2016). Possible applications of crop modeling are understanding the drivers of yield levels under climate change and promoting adaptation planning and response to changing production risks (Webber et al., 2018). In this paper, a deterministic biogeochemical model is presented that is developed by Hungarian scientists within the framework of the AgroMo project.

\section{Materials and methods}

Modeling is an essential tool in agricultural systems science (Jones et al., 2017). Different types of models are developed and used depending on the purpose of use and spatial and temporal scales (Fodor et al., 2017). Climate or environmental index-based methods determine the vulnerability of the studied agricultural area on production factors that are characterized by multidimensional scoring system (Olesen et al., 2011). Statistical models use regression equations to show linkage between yield or yield components and climate variables (Kern et al., 2018; Leng and Huang, 2017; Lobell and Burke, 2010). Niche-based models define the geographical distribution of a crop species and specify the concerning environmental suitability expressed on a scale (0-1) (Estes et al., 2013). Process based or dynamic crop models synthesize the latest scientific understanding of biophysical processes and are currently the primary scientific tools available to assess potential impacts of climate change on crop production (Bindi et al., 2015). The complexity of risks posed by climate change and possible adaptations for crop production requires integrated assessment and modeling (IAM) approaches linking biophysical, geochemical, and economic models (Ewert et al., 2015). Jones et al. (2017) pins out that recent trends in broader collaboration across institutions, across disciplines, and between the public and private sectors suggest that the stage is set for the major advances in agricultural systems science that are needed for the next generation of models, databases, knowledge products, and 
decision support systems. International model comparison projects like the Agricultural Model Intercomparison and Improvement Project (Rosenzweig et al., 2013) and the Modelling European Agriculture with Climate Change for Food Security (Bindi et al., 2015) show that there is a major international effort linking the climate, crop, geochemical, and economic modeling communities with cutting-edge information technology to produce improved systems models and the next generation of climate impact projections for the agricultural sector.

\subsection{The AgroMo project}

The main goal of the AgroMo project is to develop climate-smart strategies in order to mitigate the effect of potential future hazards in the context of climate change. The AgroMo project is carried out by a multidisciplinary group of scientist from the related research areas: meteorology, climatology, soil physics, soil chemistry, soil biology, plant physiology, plant nutrition, plant breeding, agro-economy, and informatics implementing four major tasks:

1) To create a complex experimental platform by combining multiple long-term experiments and newly established state-of-the-art experiments with the latest info-communication, remote sensing, and data mining techniques in order to produce large amount, good quality observed data for developing and calibrating deterministic simulation models.

2) To produce 10 continuous, bias-corrected, daily-step climate projections for the 2006-2100 period based on the RCP4.5 and RCP8.5 scenarios using different GCM-RCM combinations. These projections, together with the 10 already existing SRES A1B based projections (Dobor et al., 2015) will be used to predict the potential impact of climate change on the agricultural sector of the Carpathian Basin.

3) To develop an integrated assessment and modeling framework (AgroMo) by combining the 4M crop simulation model (Fodor et al., 2003), the BiomeBGC biogeochemical model (Thornton, 2000), and a simple agroeconomical model in order to support decision makers at multiple scales: from plot level to country level. The AgroMo system will be capable of: (a) simulating every major land use types (arable land, pasture, forest) as well as the key soil processes including $\mathrm{CO}_{2}$ and $\mathrm{N}_{2} \mathrm{O}$ emissions; (b) simulating plots; (c) simulating extended areas (using a gridded database of soil and climatic data). It will work for Hungary as a default, but European and even World wide datasets can be linked in a plug\&play manner; (d) carrying out inverse modeling for calibration (parameter estimation); (e) supporting ensemble runs: using many climate projections and/or using alternative routines for key processes (e.g., photosynthesis based on the Farquhar model vs Beer-Lambert Law); (f) calculating the economic consequences of 
specific agromanagement changes (e.g., intensification of fertilization or starting irrigation) as well as of land use changes.

4) To analyze/simulate a great number of adaptation strategies (irrigation, earlier sowing, etc.) that can be used for supporting decision makers in promoting sustainable and climate-smart agricultural activities.

\subsection{The AgroMo experimental platform}

Beside installing a great number of environmental monitoring sensors (soil respiration, soil moisture content, soil temperature, NDVI, etc.) in several longterm field experiments, the project is supported by a newly launched experimental infrastructure comprising a 3-ring FACE experiment, two eddy-covariance stations, and a 12-column lysimeter station.

Free-air carbon dioxide enrichment (FACE) is a climate manipulation technique performed in open field conditions (Ainsworth and Long, 2005). Using FACE technology, $\mathrm{CO}_{2}$ concentration is increased within circular areas and is kept at a relatively stable level (typically 100-200 ppm above current atmospheric levels) for longer time intervals. Elevated $\mathrm{CO}_{2}$ concentration is expected to affect photosynthetic activity, evapotranspiration, plant growth and many other processes that affect crop yield quantity and quality. FACE is believed to provide the most realistic measure to estimate the effect of increasing $\mathrm{CO}_{2}$ concentration on plant processes (Ainsworth et al., 2008). In the FACE rings at Martonvásár, 3 different cultivars are planted in 2 fertilizer levels, and the target $\mathrm{CO}_{2}$ concentration is $600 \mathrm{ppm}$. This dataset will be used to benchmark the AgroMo system in terms of parameterization of the model for simulating the response of plant processes to increasing atmospheric $\mathrm{CO}_{2}$ burden.

Eddy covariance (EC) is a micrometeorological measurement technique that is widely used to quantify the exchange of $\mathrm{CO}_{2}$ and water vapor between terrestrial ecosystems and the atmosphere (Baldocchi, 2003). Eddy covariance systems use fast response gas analyzers and sonic anemometers to sample atmospheric turbulence. Based on the turbulent signal it is possible to estimate the so-called net ecosystem exchange of $\mathrm{CO}_{2}$ (typically called NEE), which is the net $\mathrm{CO}_{2}$ flux between the atmosphere and the plant/soil system at the field scale. Using state-of-the-art mathematical methods NEE is further processed to calculate gross primary production (GPP, which is equivalent with plant photosynthesis) and total ecosystem respiration (TER or $\mathrm{R}_{\mathrm{eco}}$, which is the sum of autotrophic and heterotrophic respiration of the ecosystem). Latent heat flux is also routinely measured by the EC towers and then is used to calculate evapotranspiration (ET). EC measurements are typically operated continuously for many years, thus they provide invaluable and rich dataset to quantify plant carbon and water balance processes. Within the framework of AgroMo, two EC towers were established close to Martonvásár (near Pettend and Kajászó) providing NEE, GPP, TER, and 
ET at half hourly resolution. Long term operation of these EC towers will provide substantial information about the carbon balance of typical crop rotations in Hungary.

The AgroMo lysimeter station comprises twelve $2 \mathrm{~m}$ high and $1 \mathrm{~m}^{2}$ crosssection area undisturbed soil columns. Soil temperature, soil water content, and soil water potential sensors were inserted in the columns at 10 different depths, and the columns were set on sensitive scales that are capable of detecting $1 \mathrm{~mm}$ of precipitation or evaporation. The drain water exiting the columns at the bottom is also collected in vessels that are also placed on sensitive scales. Measurements are taken in every minute. Data collected within a day are uploaded to the FTP server of the AgroMo project at the end of each day. The collected data will be used for testing and improving the water and heat balance related subroutines (e.g., evapotranspiration calculation) of the AgroMo model.

\subsection{The AgroMo biogeochemical model}

The core element in the AgroMo system is the hybrid 4M - Biome-BGCMuSo simulation model. The 4M crop simulation model (Fodor et al., 2012) is a dailystep, deterministic model whose computations are determined by the numerical characteristics (defined by input parameters) of the atmosphere-soil-plant system. Besides the data that describe the physical, chemical, and biological profile of the system, it is also necessary to set its initial, boundary, and constraint conditions in the input file of the model. The parameters regulate the functions and equations of the model: the development and growth of plants and the heat, water, and nutrient balance of the soil. The initial conditions are the measured system variables at the beginning of the simulation run, e.g., the water or nutrient content of the soil. The boundary conditions are primarily the daily meteorological data, such as global radiation, temperature, and precipitation. The constraint conditions cover the numerical representation of human activities, e.g., data about planting, harvest, fertilization, or irrigation. Besides the plant development and growth, the model calculates the water, heat, and nitrogen flow as well as the nitrogen transformation processes of the soil: for example, the amount of nitrate that percolates down under the root zone and the amount of $\mathrm{NO}_{\mathrm{x}}$ gases released from the soil due to denitrification (Fig. 1).

Biome-BGCMuSo was developed from the Biome-BGC family of models (Thornton, 2000), and in this sense it is an extension and generalization of the Forest-BGC model for the description of different vegetation types including C3 and C4 grasslands (Running and Coughlan, 1988; Thornton, 2000; Trusilova et al., 2009). During the past years, our research group developed an updated version of Biome-BGC (called Biome-BGCMuSo - where the abbreviation refers to Multilayer Soil Module) to improve the ability of the model to simulate carbon and water cycle in managed ecosystems, with options for managed croplands, grasslands, and forests. The modifications included structural improvements of 
the model (e.g., the simple, outdated, one-layer soil module was replaced by a multilayer soil module; drought related plant senescence was implemented; model phenology was improved) and also management modules were developed (e.g., to simulate mowing, grazing, fertilization, ploughing, sowing, harvesting, forest thinning, and clearcut) (Fig. 1). Beyond these modifications, additional modules were developed to simulate cropland management (e.g., planting, harvest, ploughing, and application of fertilizers). Forest thinning was also implemented as a possible human intervention, and dynamic (annually varying) whole plant mortality was implemented in the model to enable more realistic simulation of forest stand development. The modifications were published in detail in Hidy et al. (2012, 2016).

Biome-BGCMuSo uses meteorological data, site-specific data, ecophysiological data, carbon-dioxide concentration and nitrogen deposition data to simulate the biogeochemical processes of the given biome. The main simulated processes assessed are photosynthesis, allocation, litterfall, carbon, nitrogen and water dynamics in the plant, litter as well as in the soil. The most important blocks of the model are the carbon flux block, the phenological block, and the soil flux block. In the carbon flux block, gross primary production of the biome is calculated using Farquhar's photosynthesis routine (Farquhar et al., 1980). Autotrophic respiration is separated into maintenance and growth respirations. Maintenance respiration is the function of the nitrogen content of living material, while growth respiration is calculated proportionally to the carbon allocated to the different plant compartments. The phenological block calculates foliage development; therefore, it affects the accumulation of carbon and nitrogen in leaf, stem, root, and litter. The soil block describes the decomposition of dead plant material and soil carbon pools (Running and Gower, 1991).

The $4 \mathrm{M}$ model was integrated in the Biome-BGCMuSo by reimplementing the algorithm codes of $4 \mathrm{M}$ in the Biome-BGCMuSo program code, and including the $4 \mathrm{M}$ specific input parameters in the Biome-BGCMuSo input files. The AgroMo model simulation consists of two main phases. The first is the spinup simulation (in other words self-initialization, or equilibrium run), which starts with very low initial level of soil carbon and nitrogen, and runs until a climate and soil specific steady state is reached in order to estimate the initial values of the state variables (mostly soil carbon and nitrogen pools including recalcitrant soil organic matter, the latter is being the primary source of nitrogen mineralization in the model (Thornton, 2000). The second phase is the normal simulation that uses the results of the spinup simulation as initial values for the carbon and nitrogen pools. 


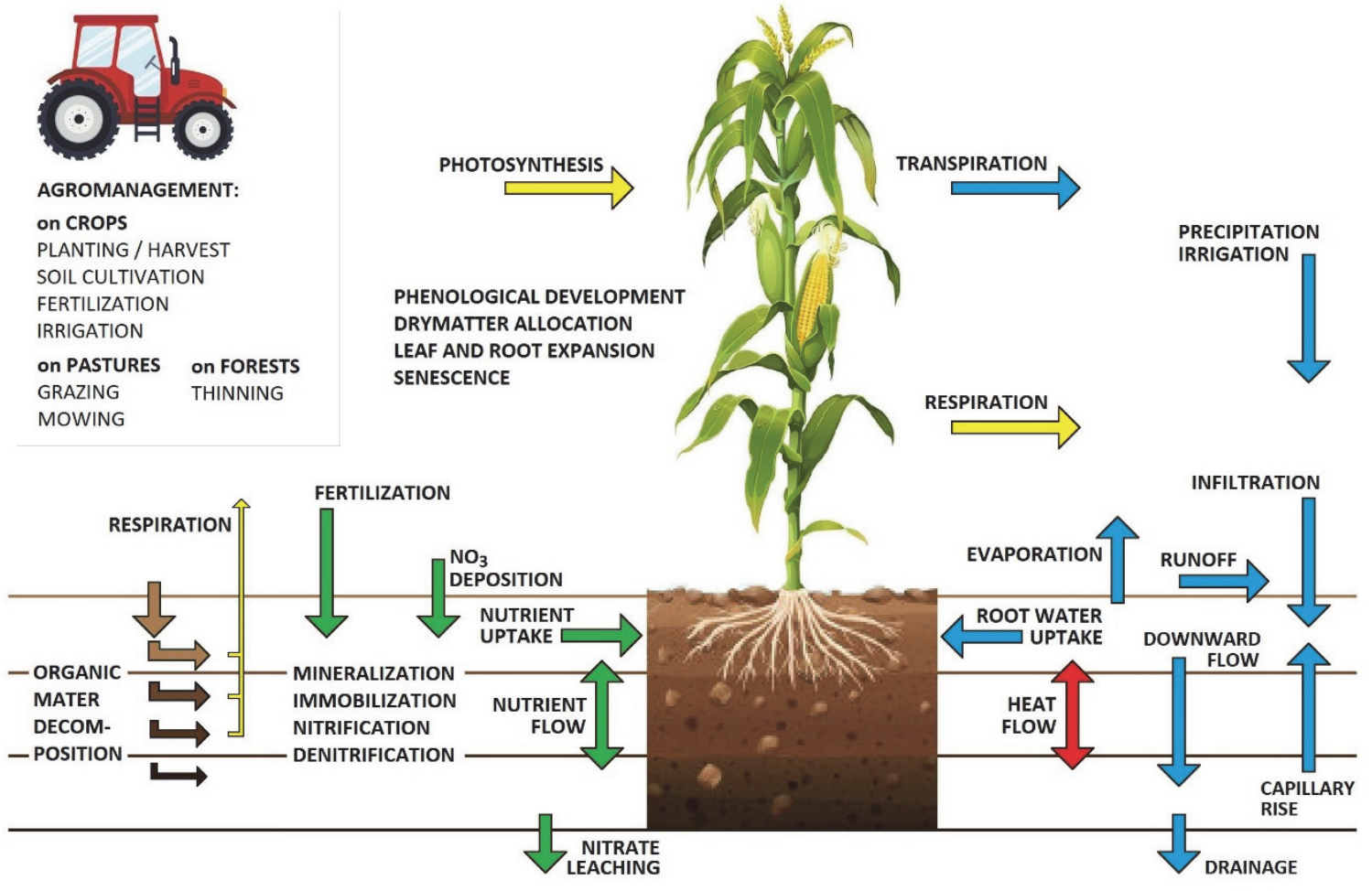

Fig. 1. Major processes simulated by the AgroMo model.

\section{Results and case studies}

In general, biogeochemical models could be successfully applied in the following areas: (1) Education: by promoting the system-oriented thinking, a comprehensive overview of the interrelations of the soil-plant system as well as of the environmental protection related aspects of the human activities could be presented. (2) Research: The results of observations and experiments could be extrapolated in time and space, thus, for example, the possible effects of climate change could be estimated. (3) Practice: Model calculations could be used in intelligent irrigation control and decision supporting systems as well as for providing scientific background for policy makers. AgroMo is designed to mimic the Hungarian agriculture (Fig. 2): the impacts of actions in the reality (R) are simulated in the virtual reality (VR). A graphical user interface (GUI) was designed for translating real life problems into modeling tasks as well as for publishing model results in easily comprehensible ways. AgroMo stores its data in a SQLite database (SQLite, 2019) designed to provide quick and complex queries but, it also uses data from external data sources (DS) such as Hungarian Central Statistical Office datasets. 


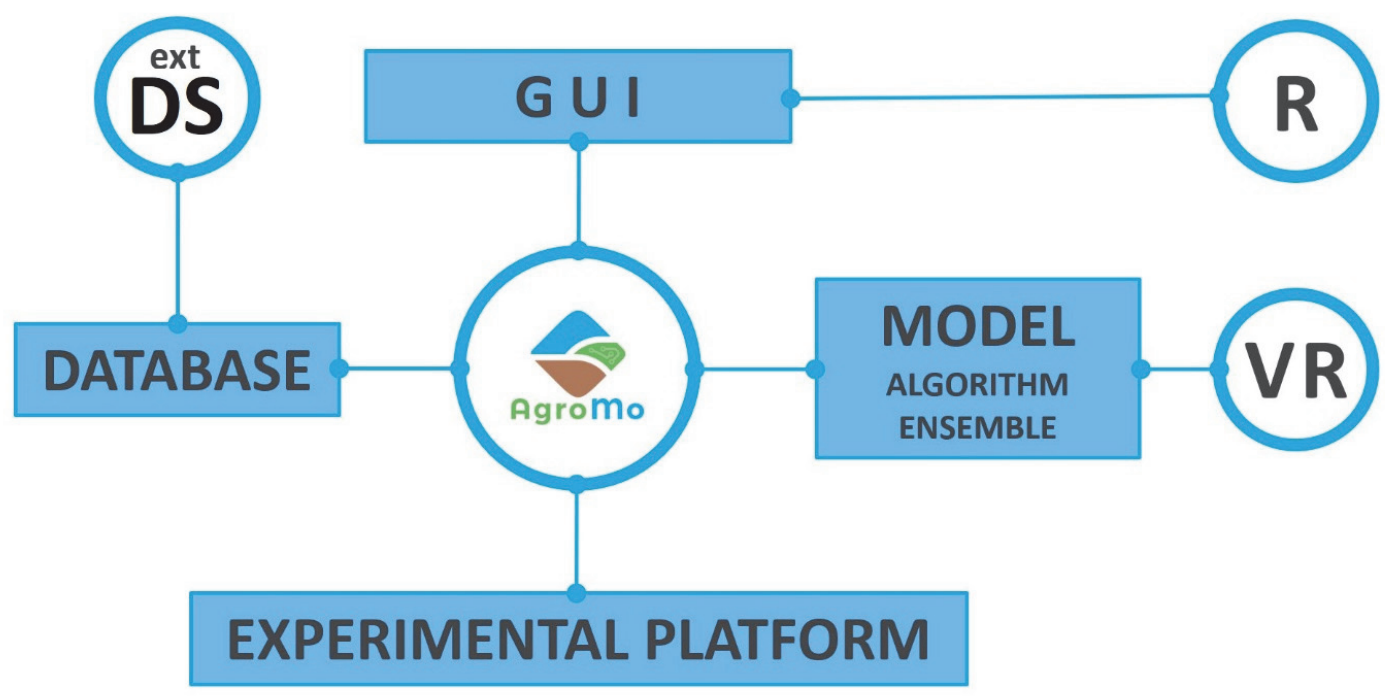

Fig. 2. Structure of the AgroMo system. DS: external data sources, DATABASE: SQLite tables, GUI: graphical user interface, R: reality, VR: virtual reality.

Undoubtedly, the most important way of using biogeochemical models is decision support. Models can even be used for resolving scientific arguments between experts. Representatives of the European Union revise the practical realization of the Nitrate Directive (91/676/EEC) in every five years (European Comission, 2018). Based on the collected experiences, the EU proposes amendments to the Directive for every member state in order to minimize the risk of one of the most important ecosystem disservices: the nitrate leaching of agricultural origin. One of the most recent proposed amendments is the idea of extending the spring fertilization prohibition period. At present, it is allowed to apply fertilizers starting from February 1 . According to the proposal, this date would be moved to March 1 . Though one can assume that it is highly unlikely that a portion of the fertilizer applied on the soil surface can go through the continuously deepening root zone without taken up by the plants, someone else can be more aware of the environment protection aspects. The Hungarian experts usually emphasize the yield safety in this matter, while EU experts tend to focus on the increasing risk of subsurface water contamination. A debate has been developed along the following questions: Does the earlier fertilization increase the risk of nitrate leaching significantly? Could the initiative to lengthen the fertilization prohibition period be substantiated scientifically? Experimentally, these questions could be answered only by time-consuming and expensive longterm field trials. Since we do not have years to find the answers by measurements, the only remaining scientific tool that is able to handle this problem is a biogeochemical model. Using the available soil (Pásztor et al., 2013) and climatic 
(Spinoni et al., 2015) databases, 50-year-long crop rotations (maize - winter wheat, winter wheat - rapeseed, winter barley - rapeseed, silage maize - winter barley) were simulated for every major soil type (from sand to clay) in Hungary. Three fertilization scenarios were investigated for each of the rotation that differed only in the date of the first spring fertilization: I) February 1; II) February 15; III) March 1 . The yields as well as the annual nitrate leaching amounts were calculated by the model, and the latter is presented in Fig. 3. According to the results, the amount of nitrate leaching does not increase as the date of the first spring fertilization moves from the end of February to the beginning of the month. On the other hand, if the prohibition period have been lengthened with one month, the yields of the winter crops would significantly decrease independently of the soil type due to the increased nutrient shortage in the early vegetative phase. Consequently, there is no need for extending the fertilization prohibition period by moving its end to March 1, as in fact it may cause yield loss. Leaving the prohibition period as it is today will not increase the risk of contaminating the subsurface water reservoirs due to nitrate leaching.

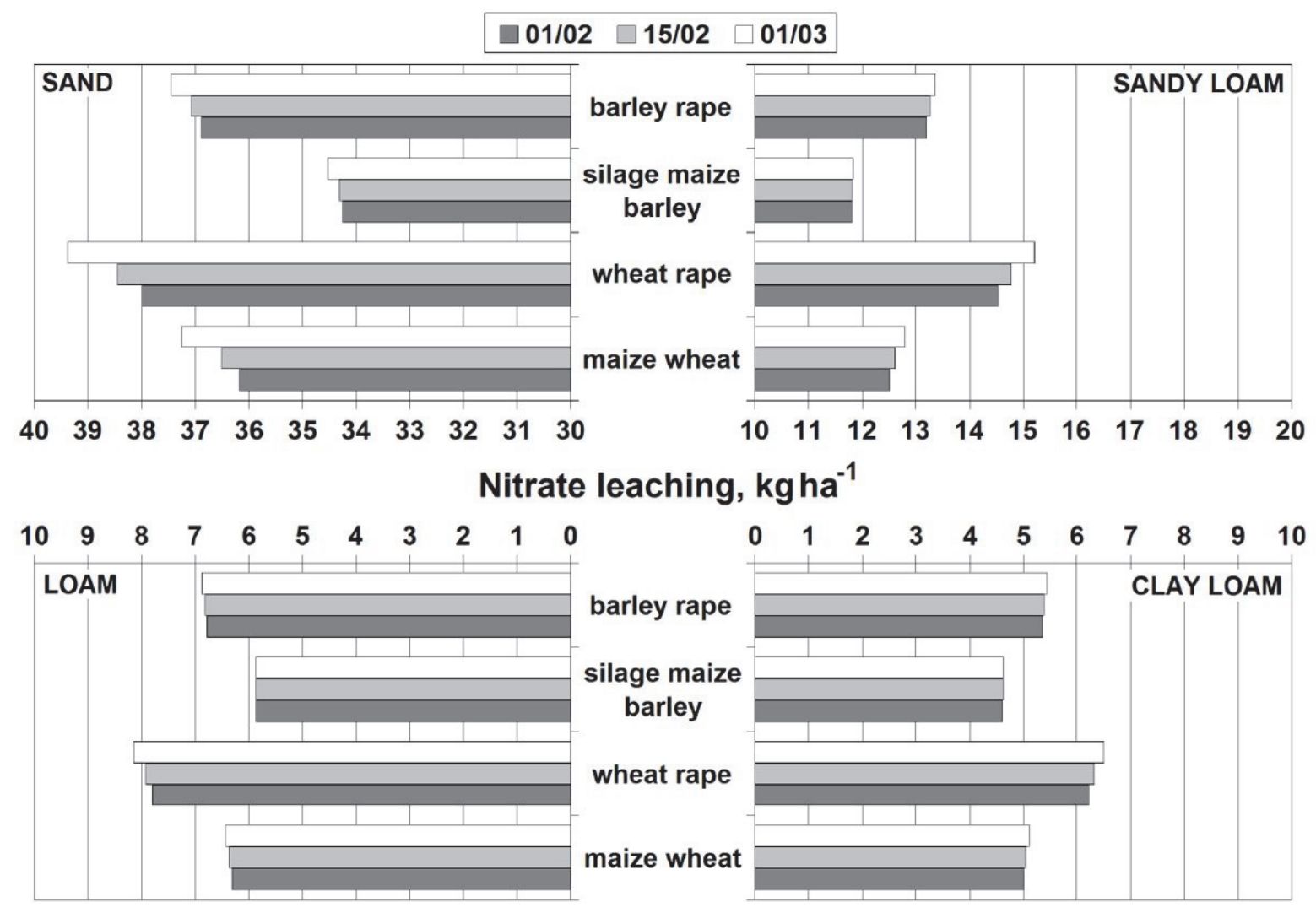

Fig. 3. Annual nitrate leaching rates as a function of the first spring fertilization date (dd/MM) of winter crops based on 50-year-long simulations (1961-2010). 
Unquestionably, the most important ecosystem service of agricultural lands is the yield or production of the plants. In the context of climate change, one of the most burning questions is how the level of production will change due to the gradually changing environmental conditions. This question could also be answered by coupling biogeochemical models with regional gridded geodatabases. Within the frame of a pilot project, we analyzed the possible impacts of climate change on Hungarian crop yield. In this case, the climatic database was based on daily meteorological data measured at the weather stations of the Hungarian Meteorological Service and spatially interpolated for a cc. $10 \times 10$ $\mathrm{km}^{2}$ resolution grid in the framework of the CarpatClim project (Spinoni et al., 2015). The observation-based dataset is freely available for the 1961-2010 period. The applied data contained future climate simulations based on the IPCC SRES A1B scenario (Nakicenovic and Swart, 2000). The climate scenario was constructed based on the outputs of the ARPEGE-CLIMATE GCM (Déqué et al., 1998) and ECHAM GCM (Roeckner et al., 2006), which were then dynamically downscaled for Hungary with two different the regional climate models: ALADIN (Csima and Horányi, 2008) and REGCM (Torma et al., 2008), respectively. These future climate projections were available for the 2021-2050 and 2071-2100 periods with the same $10 \times 10 \mathrm{~km}^{2}$ spatial resolution as of the observation-based data. The model simulations were run using the baseline (1981-2010) and future (2051-2070 and 2071-2100) climate time series. The difference in the yield and biomass levels simulated with the baseline and future climatic conditions was assumed to be the potential impact of climate change on crop production (Table 1).

Table 1. Potential impact of climate change on the major crops in Hungary. (Ensemble average of the yields $(\mathrm{Y})$ and biomass $(\mathrm{BM})$ obtained with all the available climate projections.)

\begin{tabular}{lcccc}
\hline \hline & \multicolumn{2}{c}{$\mathbf{2 0 5 1 - 2 0 7 0}$} & \multicolumn{2}{c}{$\mathbf{2 0 7 1 - 2 1 0 0}$} \\
& $\mathrm{Y}, \mathrm{t} / \mathrm{ha}$ & $\mathrm{BM}, \mathrm{t} / \mathrm{ha}$ & $\mathrm{Y}, \mathrm{t} / \mathrm{ha}$ & $\mathrm{BM}, \mathrm{t} / \mathrm{ha}$ \\
\hline \hline maize & -0.86 & -0.77 & -2.26 & -2.61 \\
sunflower & -0.37 & -0.82 & -0.92 & -2.33 \\
winter wheat & 0.83 & 1.52 & 1.36 & 2.68 \\
winter barley & 0.72 & 1.34 & 1.23 & 2.46 \\
rapeseed & 0.48 & 1.72 & 0.99 & 3.70 \\
\hline
\end{tabular}


Based on the simulation results, climate change will most likely expose significant negative impact on the spring sown crops primarily due to the more frequently occurring summer droughts and the heat weaves around flowering. Though the yield losses could be avoided with irrigation or could be mitigated with earlier sowing, the role of winter crops is likely to become more significant in Hungary in the future.

\section{Conclusions and further developments}

The objectives and the first indicative results of the AgroMo project has been presented. Preliminary simulation results show that the AgroMo integrated assessment and modeling framework could be successfully used for providing scientific background for stakeholders as well as for policy makers at various scales. Beyond the complex scientific content (model development and improvement), the most important challenge of the project is to provide a user interface that can be effectively used for communicating the simulation results. Simulations, even at the default $0.1^{\circ}$ spatial resolution grid of Hungary (1104 grid points) produce enormous amount of data; literally billions of data records for only one single simulation. Using the services of the powerful SQLite (SQLite, 2019) database application, the simulation results could be presented on graphs (TimeSeries, BarChart, XYplot), in tables as well as on color coded maps. Users can use prewritten regular sentences (e.g., Average yield in the 2071-2100 period) to query the database of the results. AgroMo translates the regular sentence into an SQL query and presents the query results in the requested form (e.g., on a map). With this feature, AgroMo can support the work of any actor in the agriculture sector who does not necessarily has high level ICT skills.

Agro-economical considerations are in need to raise economic importance of sustainable development in changing biophysical conditions. The AgroMo base model produces the potential future crop yields and biomass under different climate scenarios. Hence, researchers may calculate the estimated costs of adaptation trajectories and develop accurate financial strategy plans to take control of climate change at individual level. The observed choices of farmers' managerial decisions, realized profits, and land values across the range of climate conditions allow us to assess the changes of future eco-systems at a given farm location and thus realize the essential developments in infrastructure, technology, and water supply management.

Though the current version of AgroMo is able to simulate the most important elements of the Hungarian agriculture (e.g., the effects of recurring heat stress and drought on crop yield, net primary production, and greenhouse gas balance, etc.), new developments are foreseen to extend the modeling possibilities in the future. Model self-initialization (or in other words spinup) is typically used to estimate initial conditions for the subsequent simulations. Due to the well-known 
weaknesses of the self-initialization, efforts are in progress to improve the spinup process and harmonize its results with the observed soil organic matter pools of Hungarian soils (Pásztor et al., 2013). Another exciting possibility in model development is the consideration of ozone damage in crop yield. As climate change is expected to increase the length of dry periods in Hungary that may be associated with high tropospheric ozone concentration, this effect may be important and cannot be neglected in the long term projections. Another feature that is currently missing from the AgroMo model is the quantification of the carbon cost of nitrogen acquisition via symbiotic mycorrhizal fungi, which is believed to consume a relatively large amount of primary production of plants (Brzostek et al., 2014). Moreover, crop yield quality (e.g., gluten content) related simulation possibilities are also missing from AgroMo, so the model is planned to be improved with this feature as well.

Owing to its user friendly, flexible, and cross-platform interface as well as to the adjoined databases of climatic, soil, agromanagement, and experimental data, AgroMo will be able to effectively serve the stakeholders of the agricultural sector in their everyday work.

Acknowledgement: The research was funded by the Széchenyi 2020 programme, the European Regional Development Fund, the Hungarian Government (GINOP-2.3.2-15-2016-00028), and it was supported by the grant "Advanced research supporting the forestry and wood-processing sector's adaptation to global change and the 4th industrial revolution", No. CZ.02.1.01/0.0/0.0/16_019/0000803 financed by OP RDE.

\section{References}

Ainsworth, E., Leakey, A., Ort, D.R., and Long, S.P., 2008: FACE-ing the facts. New Phytologist 179, 5-9. https://doi.org/10.1111/j.1469-8137.2008.02500.x

Ainsworth, E. and Long, S., 2005: What have we learned from 15 years of free-air CO2 enrichment (FACE)? A meta-analytic review of the responses of photosynthesis, canopy properties and plant production to rising CO2. New Phytologist 165, 351-372. https://doi.org/10.1111/j.1469-8137.2004.01224.x

Baldocchi, D.D., 2003: Assessing the eddy covariance technique for evaluating carbon dioxide exchange rates of ecosystems: past, present and future. Glob. Change Biol. 9, 479-492. https://doi.org/10.1046/j.1365-2486.2003.00629.x

Bartholy, J. and Pongrácz, R., 2005: Tendencies of extreme climate indices based on daily precipitation in the Carpathian Basin for the 20th century. Idöjárás 109, 1-20.

Bindi, M., Palosuo, T., Trnka, M., and Semenov, M., 2015: Modelling climate change impacts on crop production for food security. Climate Res. $65,3-5$. https://doi.org/10.3354/cr01342

Brzostek, E.R., Fisher, J.B., Phillips, R.P., 2014: Modeling the carbon cost of plant nitrogen acquisition: Mycorrhizal trade-offs and multipath resistance uptake improve predictions of retranslocation. $J$. Geophys. Res.: Biogeosci. 119, 1684-1697. https://doi.org/10.1002/2014JG002660

Campbell, B.M., Vermeulen, S.J., Aggarwal, P.K., Corner-Dolloff, C., Girvetz, E., Loboguerrero, A.M., Ramirez-Villegas, J., Rosenstock, T., Sebastian, L., Thornton, P.K., and Wollenberg, E., 2016: Reducing risks to food security from climate change. Glob. Food Secur. 11, 34-43.

https://doi.org/10.1016/j.gfs.2016.06.002 
Csima, G., Horányi, A., 2008: Validation of the ALADIN-Climate regional climate model at the Hungarian Meteorological Service. Időjárás 112, 155-177.

Déqué, M., Marquet, P., and Jones, R.G., 1998: Simulation of climate change over Europe using a global variable resolution general circulation model. Climate Dynamics 14, 173-189. https://doi.org/10.1007/s003820050216

Dobor L, Barcza Z, Hlásny T, Havasi Á, Horváth F, Ittzés P, Bartholy J. 2015: Bridging the gap between climate models and impact studies: the FORESEE Database. Geoscience Data Journal 2:1-11. https://doi.org/10.1002/gdj3.22

Estes, L.D., Bradley, B.A., Beukes, H., Hole, D.G., Lau, M., Oppenheimer, M.G., Schulze, R., Tadross, M.A., Turner, W.R., 2013: Comparing mechanistic and empirical model projections of crop suitability and productivity: implications for ecological forecasting. Glob. Ecol. Biogeogr. 22, 1007-1018. https://doi.org/10.1111/geb.12034

EuropeanComission, 2018. Report from the Commission to the Council and the European Parliament on the implementation of Council Directive 91/676/EEC concerning the protection of waters against pollution caused by nitrates from agricultural sources based on Member State reports for the period 2012-2015. Report no. COM(2018) 257 final.

Ewert, F., Rötter, R.P., Bindi, M., Webber, H., Trnka, M., Kersebaum, K.C., Olesen, J.E., van Ittersum, M.K., Janssen, S., Rivington, M., Semenov, M.A., Wallach, D., Porter, J.R., Stewart, D., Verhagen, J., Gaiser, T., Palosuo, T., Tao, F., Nendel, C., Roggero, P.P., Bartosová, L., Asseng, S., 2015: Crop modelling for integrated assessment of risk to food production from climate change. Environ. Model. Software 72, 287-303. https://doi.org/10.1016/j.envsoft.2014.12.003

$F A O, I F A D, U N I C E F, W F P, W H O, 2017$. Building Resilience for Peace and Food Security. Rome: FAO. Report no.

Farquhar, G.D., von Caemmerer, S., Berry, J.A., 1980: A biochemical model of photosynthetic CO2 assimilation in leaves of C3 species. Planta 149, 78-90. https://doi.org/10.1007/BF00386231

Fodor, N., Challinor, A., Droutsas, I., Ramirez-Villegas, J., Zabel, F., Koehler, A-K., Foyer, C., 2017: Integrating Plant Science and Crop Modeling: Assessment of the Impact of Climate Change on Soybean and Maize Production. Plant Cell Physiol. 58,1833-1847. https://doi.org/10.1093/pcp/pcx141

Fodor, N., Máthéné-Gáspár, G., Németh, T., 2012: Modeling the Nutrient Balance of the Soil-Plant System using the 4M Simulation Model. Commun. Soil Sci. Plant Anal. 43, 60-70. https://doi.org/10.1080/00103624.2012.631415

Fodor, N., Máthéné-Gáspár, G., Pokovai, K., and Kovács, G., 2003: 4M-software package for modelling cropping systems. Eur. J. Agronomy 18, 389-393. https://doi.org/10.1016/S1161-0301(02)00126-0

Hidy, D., Barcza, Z., Haszpra, L., Churkina, G., Pintér, K., and Nagy, Z., 2012: Development of the Biome-BGC model for simulation of managed herbaceous ecosystems. Ecol. Model. 226, 99-119. https://doi.org/10.1016/j.ecolmodel.2011.11.008

Hidy, D., Barcza, Z., Marjanovic, H., Ostrogovic Sever, M.Z,, Dobor, L., Gelybó, G., Fodor, N., Pintér, K., Churkina, G., Running, S., Thornton, P., Bellocchi, G., Haszpra, L., Horváth, F., Suyker, A., and Nagy, Z., 2016: Terrestrial ecosystem process model Biome-BGCMuSo v4.0: summary of improvements and new modeling possibilities. Geosci. Model Dev., 4405-4437.

Jacob, D., Petersen, J., Eggert, B., Alias, A., Christensen, O.B., Bouwer, L.M., Braun, A., Colette, A., Déqué, M., Georgievski, G., Georgopoulou, E., Gobiet, A., Menut, L., Nikulin, G., Haensler, A., Hempelmann, N., Jones, C., Keuler, K., Kovats, S., Kröner, N., Kotlarski, S., Kriegsmann, A., Martin, E., van Meijgaard, E., Moseley, C., Pfeifer, S., Preuschmann, S., Radermacher, C., Radtke, K., Rechid, D., Rounsevell, M., Samuelsson, P., Somot, S., Soussana, J-F., Teichmann, C., Valentini, R., Vautard, R., Weber, B., and Yiou, P., 2014: EURO-CORDEX: new highresolution climate change projections for European impact research. Reg. Environ. Change 14, 563-578. https://doi.org/10.1007/s10113-013-0499-2

Jarvis, A., Lau, C., Cook, S., Wollenberg, E.V.A., Hansen, J., Bonilla, O., and Challinor, A., 2011: An integrated adaptation and mitigation framework for developing agricultural research: Synergies and trade-offs. Experiment. Agric. 47, 185-203. https://doi.org/10.1017/S0014479711000123

Jones, J.W., Antle, J.M., Basso, B., Boote, K.J., Conant, R.T., Foster, I., Godfray, H.C.J., Herrero, M., Howitt. R.E., Janssen, S., Keating, B.A., Munoz-Carpena, R., Porter, C.H., Rosenzweig, C., and 
Wheeler, T.R., 2017: Brief history of agricultural systems modeling. Agric. Syst. 155, 240-254. https://doi.org/10.1016/j.agsy.2016.05.014

Kern, A., Barcza, Z., Marjanović, H., Árendás, T., Fodor, N., Bónis, P., Bognár, P., Lichtenberger, J., 2018: Statistical modelling of crop yield in Central Europe using climate data and remote sensing vegetation indices. Agric. Forest Meteorol. 260-261, 300-320.

https://doi.org/10.1016/j.agrformet.2018.06.009

Kis, A., Pongracz, R., and Bartholy, J., 2017: Multi-model analysis of regional dry and wet conditions for the Carpathian Region. Int. J. Climatol. 37, 4543-4560. https://doi.org/10.1002/joc.5104

Knutti, R. and Sedláček, J., 2012: Robustness and uncertainties in the new CMIP5 climate model projections. Nat. Climate Change 3, 369. https://doi.org/10.1038/nclimate1716

Lakatos, M. and Bihari, Z., 2011. A közelmúlt megfigyelt hömérsékleti-és csapadéktendenciái. In (eds. Batholy, J., Bozó, L., Haszpra, L.) Klímaváltozás - 2011: Klímaszcenáriók a Kárpátmedence térségére. Budapest, Magyar Tudományos Akadémia és Eötvös Loránd Tudományegyetem Meteorológiai Tanszék. 146-169. (In Hungarian)

Lakatos, M., Szentimrey, T., and Bihari, Z., 2011: Application of gridded daily data series for calculation of extreme temperature and precipitation indices in Hungary. Idojjárás 115, 99-109.

Leng, G. and Huang, M., 2017: Crop yield response to climate change varies with crop spatial distribution pattern. Scientific Rep. 7, 1463. https://doi.org/10.1038/s41598-017-01599-2

Lobell, D.B. and Burke, M.B., 2010: On the use of statistical models to predict crop yield responses to climate change. Agric. Forest Meteorol. 150, 1443-1452. https://doi.org/10.1016/j.agrformet.2010.07.008

Meehl, G.A., Covey, C., Delworth, T., Latif, M., McAvaney, B., Mitchell, J.F.B., Stouffer, R.J., and Taylor, K.E., 2007: THE WCRP CMIP3 Multimodel Dataset: A New Era in Climate Change Research. Bull. Amer. Meteorol. Soc. 88, 1383-1394. https://doi.org/10.1175/BAMS-88-9-1383

Nakicenovic, $N$. and Swart, R., 2000: Special report on emission scenarios. Cambridge University Press.

Olesen, J., Trnka, M., Kersebaum, K., Skjelvåg, A., Seguin, B., Peltonen-Sainio, P., Rossi, F., Jerzy, K., and Micale, F., 2011: Impacts and adaptation of European crop production systems to climate change. Eur. J. Agronomy 34, 96-112. https://doi.org/10.1016/j.eja.2010.11.003

Pásztor, L., Szabó, J., Bakacsi, Z., and Laborczi, A., 2013: Elaboration and applications of spatial soil information systems and digital soil mapping at Research Institute for Soil Science and Agricultural Chemistry of the Hungarian Academy of Sciences. Geocarto International 28, 13-27. https://doi.org/10.1080/10106049.2012.685895

Pieczka, I., Pongrácz, R., Bartholy, J., and Szabóné André K., 2018: Future temperature projections for Hungary based on RegCM4.3 simulations using new Representative Concentration Pathways scenarios. Int. J. Glob. Warming 15, 277-292. https://doi.org/10.1504/Ijgw.2018.10014245

Pongrácz, R., Bartholy, J., and Kis, A., 2014: Estimation of future precipitation conditions for Hungary with special focus on dry periods. Időjárás 118, 305-321.

Porter, J., Xie, L., Challinor, A., Cochrane, K., Howden, S., Iqbal, M., Lobell, D., and Travasso, M., 2014. Chapter 7: Food security and food production systems. In: Climate Change 2014: Impacts, Adaptation, and Vulnerability. Part A: Global and Sectoral Aspects. Contribution of Working Group II to the Fifth Assessment Report of the Intergovernmental Panel on Climate Change, Cambridge University Press. 485-533.

Power, A. 2010: Ecosystem services and agriculture: tradeoffs and synergies. Phil.Transact. Roy. Soc. B: Biol. Sci. 365, 2959-2971. https://doi.org/doi:10.1098/rstb.2010.0143

Roeckner, E., Brokopf, R., Esch, M., Giorgetta, M., Hagemann, S., Kornblueh, L., Manzini, E., Schlese. U., and Schulzweida, U., 2006: Sensitivity of simulated climate to horizontal and vertical resolution in the ECHAM5 atmosphere model. J. Climate 19, 3771-3791. https://doi.org/10.1175/jcli3824.1

Rosenzweig, C., Jones, J.W., Hatfield, J.L., Ruane, A.C., Boote, K.J., Thorburn, P., Antle, J.M., Nelson, G.C., Porter, C., Janssen, S., Asseng, S., Basso, B., Ewert, F., Wallach, D., Baigorria, G., Winter, J.M., 2013: The Agricultural Model Intercomparison and Improvement Project (AgMIP): Protocols and pilot studies. Agric. Forest Meteorol. 170, 166-182.

https://doi.org/10.1016/j.agrformet.2012.09.011 
Running, S.W. and Coughlan, J.C., 1988: A General Model of Forest Ecosystem Processes for Regional Applications I. Hydrologic Balance, Canopy GAS Exchange and Primary Production Processes. Ecol. Model. 42, 125-154. https://doi.org/10.1016/0304-3800(88)90112-3

Running, S.W. and Gower, S.T., 1991: FOREST-BGC, A general model of forest ecosystem processes for regional applications. II. Dynamic carbon allocation and nitrogen budgets. Tree physiol. 9, 147-160.

Spinoni, J., Szalai, S., Szentimrey, T., Lakatos, M., Bihari, Z., Nagy, A., Németh, Á., Kovács, T., Mihic, D., Dacic, M., Petrovic, P., Kržič, A., Hiebl, J., Auer, I., Milkovic, J., Štepánek, P., Zahradnícek, P., Kilar, P., Limanowka, D., Pyrc, R., Cheval, S., Birsan, M-V., Dumitrescu, A., Deak, G., Matei, M., Antolovic, I., Nejedlik, P., Štastný, P., Kajaba, P., Bochnícek, O., Galo, D., Mikulová, K., Nabyvanets, Y., Skrynyk, O., Krakovska, S., Gnatiuk, N., Tolasz, R., Antofie, T., and Vogt, J., 2015: Climate of the Carpathian Region in the period 1961-2010: climatologies and trends of 10 variables. Int. J. Climatol. 35, 1322-1341. https://doi.org/10.1002/joc.4059

SQLite. 2019. (http://www.sqlite.org.)

Stocker, T., Alexander, L., Allen, M., IPCC Working Group Science. 2013. Climate change 2013 the physical science basis Working Group I contribution to the fifth assessment report of the Intergovernmental Panel on Climate Change. IPCC.

Taylor, K.E., Stouffer, R.J., and Meehl, G.A.. 2011: An Overview of CMIP5 and the Experiment Design. Bulletin of the American Meteorological Society 93:485-498. https://doi.org/10.1175/BAMS-D-11-00094.1

Thornton, P.E., 2000: User's Guide for Biome-BGC, Version 4.1.1. $\mathrm{ftp} / /$ daac.ornl.gov/data/model_archive/BIOME_BGC/biome_bgc_4.1.1/ comp/bgc_users_guide_411.pdf)

Torma, C., Bartholy, J., Pongrácz, R., Barcza, Z., Coppola, E., and Giorgi, F., 2008: Adaptation and validation of the RegCM3 climate model for the Carpathian Basin. J. Climate 112, 233-247.

Trusilova, K., Trembath, J., and Churkina, G., 2009: 16: Parameters estimation and validation of the terrestrial ecosystem model BIOME-BGC using eddy-covariance flux measurements. https://doi.org/10.4126/98-004414248

Webber, H., Ewert, F., Olesen, J., Müller, C., Fronzek, S., Ruane, A., Bourgault, M., Martre, P., Ababaei, B., Bindi, M., Ferrise, R., Finger, R., Fodor, N., Gabaldón-Leal, C., Gaiser, T., Jabloun, M., Kersebaum, K., Lizaso, J., Lorite, I., and Wallach, D., 2018: Diverging importance of drought stress for maize and winter wheat in Europe. Nat. Commun. 9, 4249. https://doi.org/10.1038/s41467-018-06525-2

Wheeler, T. and von Braun, J., 2013: Climate Change Impacts on Global Food Security. Science 341, 508. https://doi.org/10.1126/science.1239402 